\title{
THE INFLUENCE OF ENTREPRENEURIAL CULTURE IN INDONESIA TOWARDS BUSINESS STUDENTS' INTENTIONTO BE AN ENTREPRENEUR
}

\author{
Agus Deva Adhikusuma ${ }^{1} \&$ Genoveva ${ }^{2}$ \\ Faculty of Business - President University \\ Email : genoveva@president.ac.id \\ E-mail: agusdeva02@gmail.com
}

\begin{abstract}
Human capital in Indonesia is still lack of entrepreneur which is only $3.31 \%$ became an entrepreneur in 2018, this is still lower from World Bank standard that a country should have more than $4 \%$ entrepreneur from the total population within a country. This study aims to find out the influence between education, family background, subjective norm, and perceived behavioral control towards entrepreneurial intention to faculty of business students in Jabodetabek area. The primary data in this study was gathered by distributing 186 survey questionnaires for faculty of business students in Jakarta, Bogor, Depok, Tangerang, and Bekasi (Jabodetabek) areas. This research used survey method through questionnaires, such as assumption analysis and multiple regression. The result showed Subjective Norm has no significant influence towards entrepreneurial intention. Education, Family Background, and Perceived Behavioral Control have significant influences toward Entrepreneurial Intention. This research also found that all independent variables simultaneously influence towards Entrepreneurial Intention. Adjusted $R$ square is 0.460 , it means that $46 \%$ changes in dependent variable (Entrepreneurial Intention) is influenced by independent variables such as education, family background, subjective norm, and perceived behavioral control. This is recommended for business students in Indonesia especially Jabodetabekarea should more confidence with their capabilities and have positive mindset to become entrepreneurs.
\end{abstract}

Keywords: Entrepreneurial Intention, Education, Family Background, Subjective Norm, Perceived Behavioral Control

\begin{abstract}
ABSTRAK
Sumber daya manusia di Indonesia masih kurangnya wirausaha yang hanya $3,31 \%$ menjadi wirausaha pada tahun 2018, ini masih lebih rendah dari standar Bank Dunia bahwa suatu negara harus memiliki lebih dari $4 \%$ wirausaha dari total populasi dalam suatu negara. Penelitian ini bertujuan untuk mengetahui pengaruh antara pendidikan, latar belakang keluarga, norma subyektif, dan kontrol perilaku yang dipersepsikan terhadap niat wirausaha kepada dosen mahasiswa bisnis di wilayah Jabodetabek. Data primer dalam penelitian ini dikumpulkan dengan membagikan 186 kuesioner survei untuk mahasiswa bisnis di Jakarta, Bogor, Depok, Tangerang, dan Bekasi (Jabodetabek). Penelitian ini menggunakan metode survei melalui kuesioner, seperti analisis asumsi dan regresi berganda. Hasil penelitian menunjukkan Norma Subjektif tidak berpengaruh signifikan terhadap intensi berwirausaha. Pendidikan, Latar Belakang Keluarga, dan Kontrol Perilaku Persepsi memiliki pengaruh signifikan terhadap Intensi Wirausaha. Penelitian ini juga menemukan bahwa semua variabel independen secara simultan berpengaruh terhadap Entrepreneurial Intention. Adjusted $R$ square adalah 0,460 , itu berarti
\end{abstract}


bahwa $46 \%$ perubahan dalam variabel dependen (Entrepreneurial Intention) dipengaruhi oleh variabel independen seperti pendidikan, latar belakang keluarga, norma subyektif, dan kontrol perilaku yang dirasakan. Hal ini direkomendasikan bagi siswa bisnis di Indonesia khususnya Jabodetabekarea yang harus lebih percaya diri dengan kemampuan mereka dan memiliki pola pikir positif untuk menjadi wirausaha.

Kata kunci: Intensi Wirausaha, Pendidikan, Latar Belakang Keluarga, Norma Subjektif, Kontrol Perilaku Persepsi

\section{A. INTRODUCTION}

Entrepreneurship has become important role in economic development within a country through job creation and other economic opportunities for a country (Yusuf, 2018). Youth entrepreneurship has become the agenda for many people, as well as countries faced with the challenges of youth and unemployment (United Nations Conference, 2015). According to World Bank, Human Capital is the capability of a person which will be the most important within a country for long-term investment which can make the prosperity of the future and the quality of life of its people (The World Bank, 2018).

Human capital in Indonesia is still lack of entrepreneur which is only $3.31 \%$ from total population became an entrepreneurs in 2018, this is still lower from World Bank standard that a country should have more than $4 \%$ entrepreneurs from the total population within a country said President of Indonesia, Widodo(Koran SINDO, 2017).

According to Global Report 2017/18 by Global Entrepreneurship Mentor (GEM), Indonesia Total Entrepreneurial Activity (TEA) 2017 showed a decrease percentage from the last 2 years ago, such as in 2016 with ratio $14.1 \%$ and Indonesia TEA 2015 is 17.7\%. (Global Entrepreneurship Monitor [GEM], 2018). TEA in Indonesia is lower than other Asia and Oceania countries, which is at the third lowest rank in Asian and Oceania Pacific with the percentage of 7,50\% in 2017 (Global Entrepreneurship Monitor [GEM], 2018).

\section{Total Entrepreneurial Activity (Tea) in Asia and Oceania 2017/18}

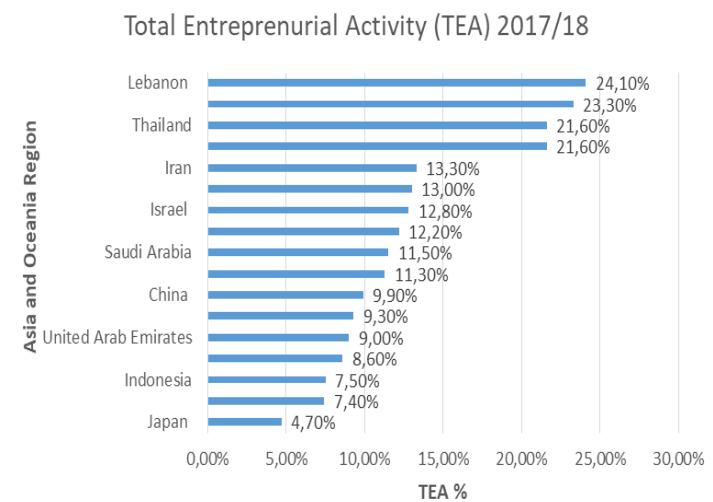

Source: (Global Entrepreneurship Monitor [GEM], 2018) 
Small ratio of TEA rate is not good for Indonesia, because it's related between TEA rates and unemployment rate (Global Entrepreneurship Monitor [GEM], 2018). When a country have many entrepreneur, it can decreasing an unemployment by job creation (Dilanchiev, 2014). Schumpeter's effect assumes that development of entrepreneurship and new start-ups will provide employment opportunities and indirectly will influence the creation of employment in other existing firms (Mahadea \& Kaseeram, 2018), (Gawel, 2010). With the example, every entrepreneur can make a job creation that help unemployment to join and support their business with the output the effectiveness of entrepreneur to decreasing unemployment by some job creation (Bokhari , 2013).

Based on data the Central Bureau of Statistics (BPS) Indonesia, Indonesia unemployment ratio reaches 5.13\% on February 2018 (Badan Pusat Statistik Indonesia, 2018). This is still a big number of the total unemployment rate in this globalization era. Indonesia have to see how the neighbor countries such as Malaysia, Singapore, and Thailand to maintaining the unemployment rate with good ratio of entrepreneurial activity. Indonesia is still high number of unemployment rate around Asia countries (Global Entrepreneurship Monitor [GEM], 2018). Unemployment rate in city higher than unemployment rate in village (Badan Pusat Statistik Indonesia, 2018).

\section{Unemployment Rate Condition in City and Village Indonesia}

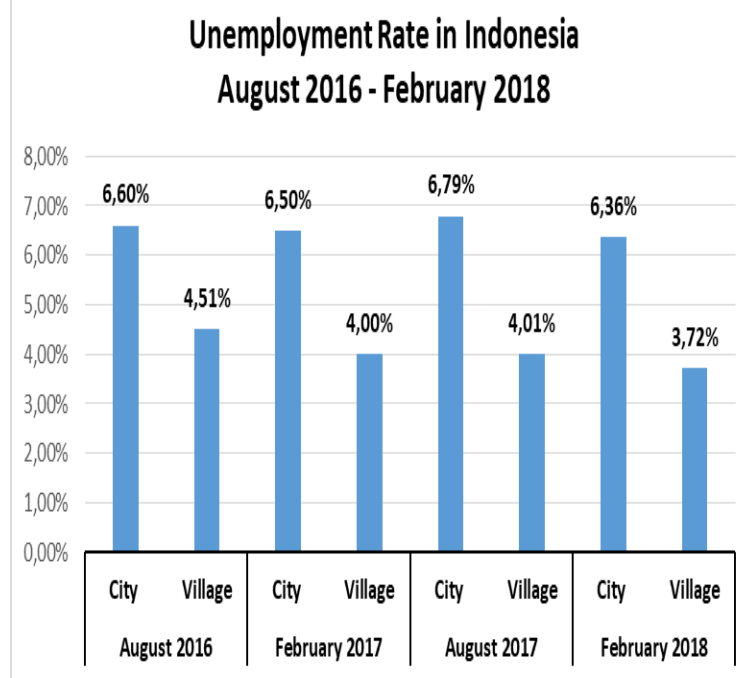

Source:(Badan Pusat Statistik Indonesia, 2018)

Many Top Indonesia universities place in city of Indonesia such as University of Indonesia, Bogor Agricultural University, and Bandung of Institute technology (QS World University Rankings, 2018). Indonesian students only focusing as an employee in best company as their career after they are graduated, which is still low intention to becoming entrepreneur as second choice when Indonesian students not accepted in any companies in Indonesia as their target (Putri, 2018; Budi, 2018). In this case, University role should more intention with entrepreneurial education, is not only for education but also for practices (Hajrah, Siswoyo, \& Rahayu, 2016).

Indonesia still lack of human resources who want to become entrepreneur and small 
entrepreneurial activity which are made Indonesia still high of unemployment rate in Indonesia especially graduates students. According to the Central Bureau of statistics (BPS) Indonesia, Unemployment rate in Indonesia had increasing in graduates students from February 2017 is 606.939 people and on February 2018 becoming 789.113 people.

\section{S1 Degree Unemployment Rate in Indonesia(February 2015 - February 2018)}

S1 Degree Unemployment Rate in Indonesia

Feb 2015 - Feb 2018

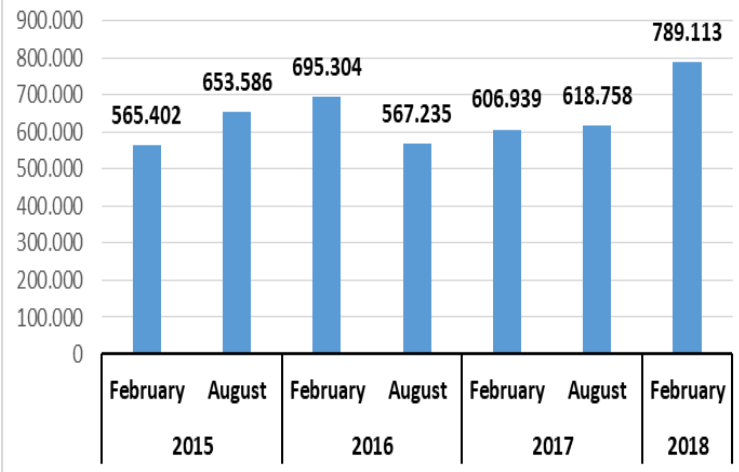

Source: (Badan Pusat Statistik (BPS) Indonesia, 2018)

The problem that faces in entrepreneurial intention ratio is small in Indonesia, starting with The curriculum of entrepreneurial subject in Indonesia still need improvement, such as not only theoretical as their score basis but need action in their education activities, lack of support to conduct an seminar events about entrepreneurial, and the output that students just think needs passed this entrepreneurial subject of their study (Wirandana \& Hidayati, 2017). Education is an important role for Indonesian to have intention to become entrepreneur. Starting from education, Indonesian students have a picture of an entrepreneurial intention into action (Utami, 2017).

Second, from family background. Family background as an important role in influencing the intention of the child to start a business (Shittu, 2014). The draw factor or positive inspiration originates from family background with parental good examples, critical family duties at a youthful age or chances to take part in entrepreneurial activities (Shittu \& Dosunmu, 2014).

Accordingly, these Childs learned and built up the abilities, values, certainty, and experience for becoming entrepreneur in the future (Shamsudin, Mamun, Nawi, Nasir, \& Zakaria, 2017). According to the theory of planned behavior by Ajzen, Intention to perform practices of various types can be anticipate with high precision from attitude toward subjective norm and perceived behavioral control (Ajzen, 1991). Subjective norm shared by critical individuals around the individual do influence individual inclinations towards performing pioneering goal and the feeling of having the capacity to do them (Joseph, 2017).

Perceived Behavioral Control as components concerning the achievement of its 
execution may not be completely up to the person (Tsordia \& Papadimitriou, 2015). For this situation, convictions of control depend on past encounters of enterprising conduct. The way of life in which it was created. Along these lines, support of political, social and business pioneers could be a key factor for the improvement of business action. Since its help gave through motivating forces empowers the development of organizations and makes more probable that business visionaries see their possibility of independent work as something conceivable.

\section{RESEARCH OBJECTIVES}

This study would like to obtain research objective, there are:

1. To find out education have a significant influence towards business students' intention to be an entrepreneur,

2. To Find out family background have a significant influence towards business students' intention to be an entrepreneur,

3. To find out subjective norm have a significant influence towards business students' intention to be an entrepreneur,

4. To find out perceived behavior control have a significant influence towards business students' intention to be an entrepreneur.

5. To find out education, family background, subjective norm, and perceived behavioral control simultaneously towards business students' intention to be an entrepreneur.

\section{B. LITERATURE REVIEWS}

\section{Entrepreneurial Intention}

According to Dhose and Walter, Entrepreneurial intention is characterized as the readiness of people to perform pioneering conduct, to take part in enterprising activity, to act naturally utilized, or to build up new business (Adebisi, 2018). Entrepreneurial intention is vital to understanding the business enterprise process since they shape the underpinnings of new associations, and the indicators are Passion with entrepreneurial activities, High of interest becoming an entrepreneur, Effort Participation becoming entrepreneur, Entrepreneur give better career rather than employee (Nguyen, 2018). In the same, Frazer and Niehm stated that entrepreneurial intention contributed by many factors such as education, family background, subjective norm, perceived behavioral control and other variables (Shamsudin A. S., 2018).

\section{Education}

Education is a productive method for outfitting understudies with suitable learning identified with business enterprise (Kadir, Salim, \& Kamarudin, 2012). According to Rae (2010), Education is to shape thoughts with respect to the importance of being entrepreneur and to create basic insight that set up to the duty of entrepreneur to the network. The indicators are Entrepreneurship subject, Business project, University contribution, Innovative students, and University society support(Ali , et al., 2017). 
According to Ismail, et al. (2009) demonstrates that students who have taken entrepreneurship subject are accounted for to have more intention to take part in entrepreneurial when contrasted with the other understudies. The researcher can see that the experience and information they got when enlisted this subject has animated their advantage and dreams to become entrepreneur.The significance of education factors on entrepreneurial intention is steady with the discoveries directed by Turker and Selcuk ( 2009).

\section{Family Background}

According to Astrachan, Klein, and Smyrnios (2016), Family is characterized as a gathering of people including the individuals who are either posterity of a couple (regardless of what age) and their in-laws and indicators' are Hard-Work, Risk-taking, Focusing on actual goals, Actives successors, and Intentional successors. Family background is one of the important role in influencing a child intention's to start a business (Shittu and Dosunmu, 2014). However, from Suffian, et al. (2018) Family background is a parents or relatives within a family who are occupied with business will in general show higher goal in contrast with the individuals who have no parent or relatives within a family that engaged with the business. This is very important for a parents and/or relatives within a family can support their children intention mindset becoming entrepreneur and parents should support give motivation, entrepreneurial activities, and support for their children how good when we will become a succeed entrepreneur (Astrachan, Klein, \& Smyrnios , 2016).

\section{Subjective Norm}

Subjective norm is traits the commitment in a specific conduct because of peer influence (Ajzen, 1991). According to Joseph, (2017), Subjective norm are a people's own judgment of the social powers to execute target conduct and it identifies with a people's conviction about whether companions and individuals of significance to the individual figure he or she ought to take part in the conduct and also the indicators are Family support as a power being entrepreneur, Best Friend support as a power being entrepreneur, Close person Society support as a power being entrepreneur, and University support. Schlaegal and Koenig stated that subjective norm is is a person's view of pertinent individuals' inspirational assumptions regarding the beginning of a claim adventure by this individual will push this person to shape positive impression of attractive quality as to the practices that are important to accomplish the objective to becoming entrepreneur (Schlaege and Koenig, 2014).

\section{Perceived Behavioral Control}

According to Ajzen, (1991), perceived behavioral control is the factor invigorate to the apparent straightforwardness or trouble playing out the conduct and it accept to reflect past understanding and in addition foresees impediment and obstacles, which implies that these elements mirror the discernments would be troublesome or not play out an 
activity and expected an impression of past experience and expectation of impediments.Perceived behavioral control is indicated as self-efficacy is where individuals trust that a conduct is simple or hard to do, with the indicators are Trust to run a business, Confidence to run a business, Good capabilities to run a business, Believe as a success entrepreneur (Cruz, Suprapti, and Yasa, 2015). Perceived Behavioral Control is elects the degree to which an individual controls convictions about the movement being examined (Tsordia and Papadimitriou, 2015).

\section{Research Gap}

In this study discussed about the influence of entrepreneurial culture in Indonesia towards business students' Intention to start a business. From previous research above, many of the research journal explain about the role theory of planned behavior and combined with the other theories as their variable and discussed in their research such as journal from (Utami, 2017; Tsordia and Papadimitriou, 2015;Naushad, 2018; Esfandiar, Tehrani, Pratt, \& Altinay, 2017; Shamsudin A. S., 2018). In research design is different enough such as from population many of previous research only using final year students with various study background. (Tsordia \& Papadimitriou, 2015) Using population comparing in first year and fourth year students, however (Utami, 2017) quite same but different place to take a population that the researcher choose which is east java and in this study using region in Jabodetabek area. The data analysis is quite same with each of previous journal such as multiple regression and SEM analysis. From those analysis had a result show that variable from theory of planned behavior has positive significant influence towards entrepreneurial intention, however previous research from (Tsordia \& Papadimitriou, 2015) and (Esfandiar, Tehrani, Pratt, \& Altinay, 2017)

\section{THEORETICAL FRAMEWORK}

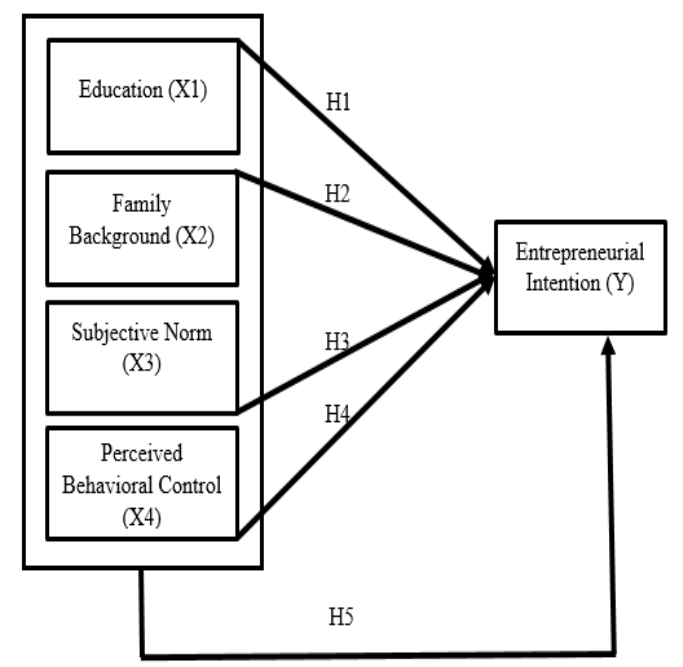

Source: Utami ( 2017); Tsordia and Papadimitriou (2015) 


\section{HYPOTHESIS}

According the literature review and theoretical framework, the researcher arranged the following hypotheses:

$\mathrm{H}_{1}$ : Education has influence towards business students' intention to be an entrepreneur.

$\mathrm{H}_{2}$ : Family background has influence towards business students' Intention to be an entrepreneur.

$\mathrm{H}_{3}$ : Subjective norm has influence towards business students' intention to be an entrepreneur.

$\mathrm{H}_{4}$ : Perceived behavioral control has influence towards business students' intention to be an entrepreneur.

$\mathrm{H}_{5}$ : There are simultaneously influence towards business students' intention to be an entrepreneur.

\section{RESEARCH INSTRUMENT}

Researcher collected primary data by distributing questionnaire to target respondents, which is as one of tools for collect the primary data. This way is more efficient and lowest cost for researcher to reach large number of respondents. Researcher analyzed and assessed all of secondary data as evidence to support all the findings for this study. All of secondary data already showed are explained in chapter 2. Researcher collected secondary data by sources from international and national journal, published statistics, and reputable website.The researcher spread the questionnaire through social media such as Line and Instagram, and also using Linked-In to spread more respondents in Jabodetabek area. The questionnaire via online through Google docs, which is more efficient to spread the questionnaire. The part of questionnaire starting with screening questions, such as the place and/or region of university which is to make sure or valid answer from respondents for this study only university are in Jabodetabek. Second questions to make sure the respondents are a students from faculty of business. The second part is consist of several questions regarding for all of variables, such as education, family background, subjective norm, perceived behavioral control, and entrepreneurial intention. 5-Likert Scale is received to enable respondents to express the amount they agree or disagree contradicting a specific explanation. It extend from "strongly disagree $=1$ " to "Strongly Agree $=5$ " (Croasmun \& Ostrom, 2011).

\section{SAMPLING DESIGN}

The population is integrated Sampling design is characterized as methods for choosing essential data for information accumulation and examination which are suitable for an actual research question (Lameck, 2013). In this study, target populations are 
undergraduate students from faculty of business in Jabodetabek (Jakarta, Bogor, Depok, Tangerang, Bekasi) area. Because of that, the population for this study is unknown.

In this study using purposive sampling from non-probability sampling. A screening questions are put in the questionnaire to make sure all of respondents for this study are student from faculty of business that are the university place in Jabodetabek area in order to get a valid answer for this study. In Determining sample size, the researcher will apply one of sampling method which is 5 times amount questions, and it is resulted that minimum of total respondents is 155 since there are 31 questions asked in the questionnaires being spread. The questionnaire is distributed to 186 respondents including the initial 30 respondents which as of now experience the pre-test and turned out to be valid and reliable. Hence the researcher continue with the valid and reliable 186 respondents to direct the real test.

\section{RESULTS \& DISCUSSION}

\section{Validity and Reliability}

In this study on validity test used product moment method person. A total of $r_{\text {tablewith }} 30$ samples and 0.05 significance equals to 0.361 (Sugiyono, Cara Mudah Menyusun Skripsi, Tesis dan Disertasi, 2013). This means that a question will be valid if a total of $r$ should be more than 0.361 . All of the questions are valid to be analysed. In reliability test, In this study using Cronbach's Alpha equation to know all of variable of this study are reliable and accurate.

The Alpha Coefficient Range should be more than 0.600 . The result found that independent variables and dependent variable are reliable with different level of consistency such as education, family background, subjective norm, and perceived behavioral control have high reliability, while entrepreneurial intention has moderate reliability.

\section{Normality Test}

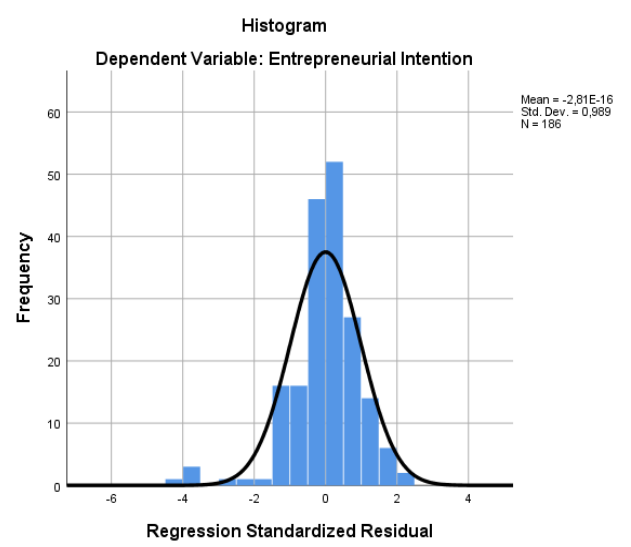

Histogram of Regression Standardized Residual 
Source: Calculated by SPSS 25.0

The result showed that It P-Plot was similarly circulated inside a corner to corner line. The dotss are scatter equitably at line and furthermore spread around the diagonal line which shows that the distribution is normal. Consequently, the figure above show to Normal P-P Plot of Regression Standardized Residual.

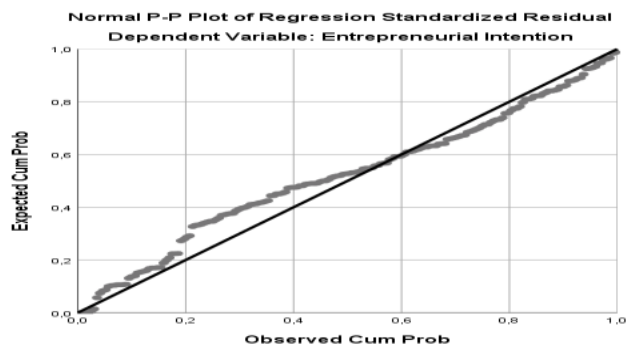

P-Plot Diagram

Source: Calculated by SPSS 25.0

Based on the figure above showed that the bell was shaped by all of data that gained by the researcher, and the information can be said as normally distributed, as it does not skewed either to one side or to one side. Along these lines, the data could be utilized to rough various discrete probability distribution and is qualified to conduct a research.

\section{Heteroscedasticity}

\section{Scatterplot (Result of Heteroscedasticity Test)}

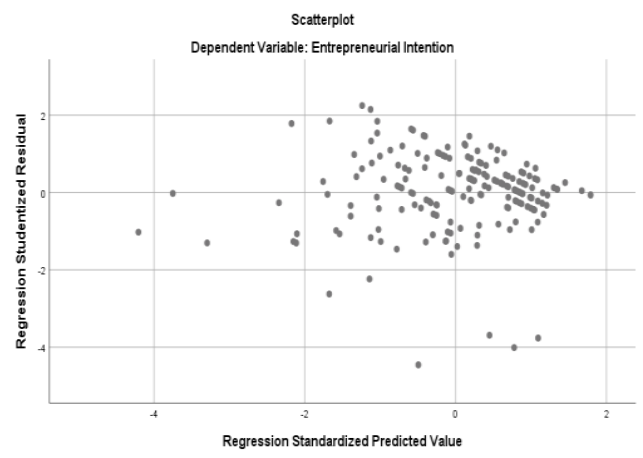

Source: Calculated by SPSS 25.0

Good regression model is going on homoscedasticity in the model or in the other words do not happen heteroscedasticity. According to Figure above appeared from the scatterplot, demonstrates that dots randomly spread either at the bottom number 0 or the top on the axis Y. Consequently, it can be conclude that there is no heteroscedasticity in this regression model of this study. The independent variables in this study are sufficiently qualified to quantify its influence towards entrepreneurial intention. 


\section{Multicollinearity Test}

\begin{tabular}{|l|l|l|l|}
\hline \multicolumn{3}{|c|}{ Coeffiecients $^{\text {a }}$} \\
\hline \multirow{2}{*}{ Model } & \multicolumn{2}{|c|}{$\begin{array}{c}\text { Collinearity } \\
\text { Statistics }\end{array}$} \\
\cline { 2 - 4 } & Tolerance & VIF \\
\hline 1 & (Constant) & \multicolumn{2}{|c|}{} \\
\cline { 2 - 3 } & Education (X1) & 0.747 & 1.339 \\
\cline { 2 - 3 } $\begin{array}{l}\text { Family } \\
\text { Background (X2) }\end{array}$ & 0.509 & 1.965 \\
\hline $\begin{array}{l}\text { Subjective Norm } \\
\text { (X3) }\end{array}$ & 0.572 & 1.747 \\
\hline $\begin{array}{l}\text { Perceived } \\
\text { Behavioral Control } \\
\text { (X4) }\end{array}$ & 0.538 & 1.859 \\
\hline $\begin{array}{l}\text { a. Dependent Variable: Entrepreneurial } \\
\text { Intention (Y) }\end{array}$ \\
\hline
\end{tabular}

Source: Calculated by SPSS 25.0

According to table above, the score of resistance for every single free factor is $>0.10$ and the score of VIF for every single autonomous variable is $<10$. The result found thatno multicollinearity problem in this study and can proceed for the multiple regression process.

\section{Multiple Regression}

\begin{tabular}{|c|c|c|c|c|c|c|}
\hline \multicolumn{7}{|c|}{ Coeffiecients $^{\mathrm{a}}$} \\
\hline \multirow{2}{*}{\multicolumn{2}{|c|}{ Model }} & \multicolumn{2}{|c|}{$\begin{array}{l}\text { Unstandardized } \\
\text { Coefficients }\end{array}$} & \multirow{2}{*}{\begin{tabular}{|c|} 
Standardized \\
Coefficients \\
Beta \\
\end{tabular}} & \multirow{2}{*}{\begin{tabular}{|l|} 
\\
$\mathrm{T}$ \\
\end{tabular}} & \multirow[b]{2}{*}{ Sig. } \\
\hline & & B & Std. Error & & & \\
\hline \multirow[t]{5}{*}{1} & (Constant) & 2.738 & 1.924 & & 1.423 & 0.156 \\
\hline & Education (X1) & 0.137 & 0.068 & 0.125 & 2.006 & 0.046 \\
\hline & $\begin{array}{l}\text { Family Background } \\
\text { (X2) }\end{array}$ & 0.202 & 0.084 & 0.182 & 2.406 & 0.017 \\
\hline & Subjective Norm (X3) & 0.171 & 0.090 & 0.136 & 1.904 & 0.058 \\
\hline & $\begin{array}{l}\text { Perceived Behavioral } \\
\text { Control (X4) }\end{array}$ & 0.354 & 0.067 & 0.389 & 5.274 & 0.000 \\
\hline \multicolumn{7}{|c|}{ a. Dependent Variable: Entrepreneurial Intention $(\mathrm{Y})$} \\
\hline
\end{tabular}

As the interpretation has explained above the formula of this study is:

$$
Y=2.738+0.137 X_{1}+0.202 X_{2}+0.354 X_{4}
$$

Where:

$\mathrm{Y} \quad=$ Entrepreneurial Intention 
$\mathrm{X} 1=$ Education

X2 = Family Background

$\mathrm{X} 4=$ Perceived Behavioral Control

\section{T-Test}

The T- test determines whether or not independent variables have a significant partial influence on the dependent variable. To find out which variable has a significant influence, it can be seen in the table below.

\begin{tabular}{|c|c|c|c|}
\hline \multicolumn{2}{|c|}{} & $t$ & Sig. \\
\hline \multirow{4}{*}{1} & (Constant) & 1.423 & 0.156 \\
\cline { 2 - 4 } & TX1 & 2.006 & 0.046 \\
\cline { 2 - 4 } & TX2 & 2.406 & 0.017 \\
\cline { 2 - 4 } & TX3 & 1.904 & 0.058 \\
\cline { 2 - 4 } & TX4 & 5.274 & 0.000 \\
\hline
\end{tabular}

Source: Calculated by SPSS 25.0

According to T-Test Result, the hypothesis accepted are as follows:

Ha1: There is significant influence of Education towards Entrepreneurial Intention

Ha2: There is significant influence Family Background towards Entrepreneurial Intention Ha3: There is no significant influence of Subjective Norm towards Entrepreneurial Intention

Ha4: There is significant Influence of Perceive Behavioral Control towards Entrepreneurial Intention

\section{F-Test}

To determine whether all independent variables have collective influence on dependent variable, F-Test was used by the researcher.

\begin{tabular}{|c|c|c|c|c|c|c|}
\hline \multicolumn{7}{|c|}{ ANOVA $^{a}$} \\
\hline \multicolumn{2}{|c|}{ Model } & $\begin{array}{l}\text { Sum of } \\
\text { Squares }\end{array}$ & Df & $\begin{array}{l}\text { Mean } \\
\text { Square }\end{array}$ & $\mathrm{F}$ & Sig. \\
\hline \multirow[t]{3}{*}{1} & Regression & 2209.395 & 4 & 552.349 & 40.391 & $0.000^{b}$ \\
\hline & Residual & 2475.169 & 181 & 13.675 & & \\
\hline & Total & 4684.565 & 185 & & & \\
\hline \multicolumn{7}{|c|}{$\begin{array}{l}\text { a. Dependent Variable: Entrepreneurial Intention (Y) } \\
\text { b. Predictors: (Constant), Perceived Behavioral Control (X4), Education (X1), } \\
\text { Subjective Norm (X3), Family Background (X2) }\end{array}$} \\
\hline
\end{tabular}


According to F-Test Result, the hypothesis accepted is:

Ha5: There is simultaneously significant influence towards Entrepreneurial Intention

\section{Coefficient of Correlation (R) and Coefficient of Determination $\left(\mathbf{R}^{2}\right)$}

\begin{tabular}{|c|c|c|c|c|c|}
\hline \multicolumn{6}{|c|}{ Model Summary ${ }^{b}$} \\
\hline Model & $\mathrm{R}$ & R Square & $\begin{array}{c}\text { Adjusted } R \\
\text { Square }\end{array}$ & $\begin{array}{l}\text { Std. Error of the } \\
\text { Estimate }\end{array}$ & $\begin{array}{l}\text { Durbin- } \\
\text { Watson }\end{array}$ \\
\hline 1 & $0.687^{\mathrm{a}}$ & 0.472 & 0.460 & 3.698 & 2.097 \\
\hline
\end{tabular}

The value of $R$ (Coefficient of Correlation) is 0.687 which is higher than significant value of 0.500 which means that the correlation between independent variables and dependent variable is strong in this study. While the adjusted $R$ square is 0.460 , it means that $46 \%$ changes in dependent variable (Entrepreneurial Intention) is influenced by independent variables such as education, family background, subjective norm, and perceived behavioral control in this study. The other $54 \%$ are influenced by other variables outside the independent variables in this study

\section{E. CONCLUSION}

The researchers draw conclusions and recommendations from the integration of quantitative analysis in the last chapter of this research. The conclusions of this research explained as follow:

1. T-test result shows that education (X1) has partially positive and significance influencing entrepreneurial intention. It means education become a driven to business student's Intention to start a business.

2. T-test result shows that family background (X2) has partially positive and significance influencing employee attractiveness. It means family background as a reason for students' Intention to start a businessby seeing the family business activities and family encouragement.

3. T-test result shows that subjective norm (X3) has not significance influencing entrepreneurial intention. It means subjective norm is not become a reason business students' Intention to start a business.

4. T-test result shows that perceived behavioral control (X4) has partially positive and significance influencing entrepreneurial intention. It means perceived behavioral control become a reason business students' Intention to start a business.

5. F-test result shows that there (Education, Family Background, Subjective Norm, and Perceived Behavioral Control)has simutaneously significance influence towards entrepreneurial intention. 


\section{F. RECOMMENDATION}

\section{For Government}

This is for Indonesia Governemnt. Based on the result of T-Test, Perceived Behavioral Control has high influence towards business students' intention to be an entrepreneur. Therefore, Indonesia Government should focus first on improving regulations instead of fundraising. Local startups should be getting funded directly from the private sector, without government intervention, as a result of open and favorable market conditions. Indonesia Government should work within a team with four key ministries will need to academic, business, and social stakeholders to devise a more concrete plan.

\section{For Future Entrepreneurs}

For future entrepreneur should prepare with innovation and creativity as the result of control behavior for future entrepreneur to see the market opportunities to make a new business that has a differentiate to other business (Innovation) and easy to use for user (Creativity)

\section{For Future Researcher}

For future researcher also can used other target sample like country to country which can help to know the other country entrepreneurial culture, so it can inspire for Indonesian business student to start a business.

\section{References}

Adebisi, K. I. (2018). Entrepreneurship Revolution, Skill Acquisition, and Entrepreneurial. KIU Journal of Social Sciences, 4(2), 131-137.

Ali , J., Jaganathan, M., Rashid, ‘. N., Zakaria, N., Gorondutse, A. H., \& Yacob, P. (2017). Determinants of Entrepreneurial Intention: Empirical Insights from. International Journal of Economic Research, 14, 160-166.

Badan Pusat Statistik (BPS) Indonesia. (2018, July 30). Pengangguran Terbuka Menurut Pendidikan Tertinggi yang Ditamatkan 1986 - 2018. Retrieved from Badan Pusat Statistik Indonesia

Website: https://www.bps.go.id/statictable/2009/04/16/972/pengangguran-terbuka-menurutpendidikan-tertinggi-yang-ditamatkan-1986---2018.html

Badan Pusat Statistik Indonesia. (2018, May 7). Februari 2018: Tingkat Pengangguran Terbuka (TPT) sebesar 5,13 persen, Rata-rata upah buruh per bulan sebesar 2,65 juta rupiah. Retrieved from Badan Pusat Statistik Indonesia Web Site: 
https://www.bps.go.id/pressrelease/2018/05/07/1484/februari-2018--tingkatpengangguran-terbuka--tpt--sebesar-5-13-persen--rata-rata-upah-buruh-perbulan-sebesar-2-65-juta-rupiah.html

Bokhari , A. A. (2013). Entrepreneurship as a Solution to Youth Unemployment in the Kingdom of Saudi Arabia. American Journal of Scientific Research, 23(87), 120134.

Croasmun, J. T., \& Ostrom, L. (2011). Using Likert-Type Scales in the Social Sciences. Journal of Adult Education, 19-22.

Dilanchiev, A. (2014). Relationship between Entrepreneurship and Unemployment: The Case of Georgia. Journal of Social Sciences, 3(2), 1-9.

Esfandiar, K., Tehrani, M. S., Pratt, S., \& Altinay, L. (2017). Understanding entrepreneurial intentions: A developed integrated structural model approach. Journal of Business Research, 1-17. Retrieved from https://doi.org/10.1016/j.jbusres.2017.10.045

Gawel, P. (2010). The Relationship between Entrepreneurship and Unemployment in the Business Cycle. Journal of International Studies, 3(1), 59-69.

Global Entrepreneurship Monitor [GEM]. (2018). Global Report 2017/18. London: Global Entrepreneurship Research Association (GERA).

Hajrah, Siswoyo, B., \& Rahayu, W. (2016). Effect of Entrepreneurial Education and Economic Condition of Parents towards an Entrepreneurship Attitudes through the Entrepreneurship Interest. IOSR Journal of Business and Management (IOSRJBM), 18(6), 105-110.

Joseph, I. (2017). Factors Influencing International Student. American Journal of Industrial and Business Management, 7, 424-428.

Kadir, M. B., Salim, M., \& Kamarudin, H. (2012). The Relationship Between Educational Support And. Procedia - Social and Behavioral Sciences , 69, 2164-2173.

Koran SINDO. (2017, December 19). Indonesia Target Jadi Pusat Ekonomi Digital. Retrieved from OKEZONEFINANCE: https://economy.okezone.com/read/2017/12/19/320/1832641/indonesia-targetjadi-pusat-ekonomi-digital

Lameck, W. U. (2013). Sampling Design, Validity and Reliability in General. International Journal of Academic Research in Business and Social Sciences, 3, 212-218. doi:DOI: 10.6007/IJARBSS/v3-i7/27

Mahadea, D., \& Kaseeram, I. (2018). Impact of Unemployment and income on entrepreneurship in post-apartheid South Africa: 1945-2015. The Southern African Journal of Entrepreneurship and Small Business Management, 10(1), 1-9. 
Nguyen, C. (2018). Demographic factors, family background. Journal of Global Entrepreneurship Research, 8(10), 1-17. doi:https://doi.org/10.1186/s40497-0180097-3

Shamsudin, A. S. (2018). Conceptualizing The Effect of Entrepreneurial Education and Industrial Interface Mix in Enhancing The Entrepreneurial Intention Amongst Graduates. Journal of Entrepreneurship Education, 8(3), 1-9.

Shamsudin, S. F., Mamun, A. A., Nawi, N. B., Nasir, N. A., \& Zakaria, M. N. (2017). Factors Effecting Eentrepreneurial Intention Among The Malaysian University Students. The Journal of Developing Areas, 51, 424-431.

Shittu, A., \& Dosunmu, Z. (2014). Family Background and Entrepreneurial Intention of Fresh. Journal of Poverty, Investment and Development, 5, 78-90.

Subarkah, A. R. (2017). Strategi City Branding Nusa Tenggara Barat Menjadikan Lombok sebagai Destinasi Pariwisata Halal. UMM Institutional Repository, 1-91.

Sugiyono. (2013). Cara Mudah Menyusun Skripsi, Tesis dan Disertasi (4th ed.). Bandung: Alfabet Bandung.

The World Bank. (2018, August 3). Investing in People to Build Human Capital. Retrieved from worldbank.org: https://www.worldbank.org/en/news/immersivestory/2018/08/03/investing-in-people-to-build-human-capital

Tsordia, C., \& Papadimitriou, D. (2015). The Role of Theory of Planned Behavior on Entrepreneurial Intention of Greek Business Students. International Journal of Synergy and Research , 4, 23-37.

United Nations Conference. (2015, February 9). Promoting entrepreneurship for development. Retrieved from unctad.org: https://unctad.org/meetings/en/SessionalDocuments/ciid29_en.pdf

Utami, C. W. (2017). Attitude, Subjective Norms, Perceived Behavior,Entrepreneurship Education and Self-efficacy toward Entrepreneurial Intention University Student in Indonesia. European Research Studies Journal, XX(2A), 475-495.

Wirandana, E., \& Hidayati, S. (2017, Desember). Pengaruh Pendidikan Kewirausahaan Terhadap Niat Berwirausaha. EDUKA Jurnal Pendidika, Hukum dan Bisnis, 1(5), 75-86.

Yusuf, A. (2018). The Role of Entrepreneurship in Economic Development in Saudi Arabia. Business and Economics Journal, 1-5. 
Vol. 5 No.1` Maret 2020

34 | H a I a m a n 